Western North American Naturalist 67(4), (C) 2007, pp. 613-617

\title{
INCREASED WILLOW HEIGHTS ALONG NORTHERN YELLOWSTONE'S BLACKTAIL DEER CREEK FOLLOWING WOLF REINTRODUCTION
}

\author{
Robert L. Beschta ${ }^{1,2}$ and William J. Ripple ${ }^{1}$
}

\begin{abstract}
Gray wolves (Canis lupus) were reintroduced into Yellowstone National Park in 1995-1996. In August 2004 we measured plant architecture of Geyer willow (Salix geyeriana) stems along three 100-m reaches of Blacktail Deer Creek in Yellowstone's northern elk (Cervus elaphus) winter range to evaluate changes in patterns of browsing and height growth following wolf reintroduction. Average browsing intensities ( $n=3$ stream reaches) of $100 \%$ in 1997 decreased to $0 \%-55 \%$ by 2003 , whereas average stem heights of $25-74 \mathrm{~cm}$ in 1997 increased to $149-268 \mathrm{~cm}$ by 2003 , indicating that willow height growth was inversely related to browsing intensity. In addition, average willow canopy cover over the streams increased from $<5 \%$ in 1997 to $14 \%-73 \%$ in 2004 . These findings were consistent with a hypothesis that increased willow heights following the 1995-1996 wolf reintroduction represent a trophic cascade involving wolves, elk, and deciduous woody vegetation.
\end{abstract}

Key words: riparian vegetation, willows, elk, wolves, trophic cascades, Yellowstone National Park.

Willows (Salix spp.) are a common component of riparian plant communities throughout the western United States, and over 20 species of this genus are found in Yellowstone National Park (NP; National Park Service 1997). These deciduous woody plants are normally capable of rapid height growth, even with periodic herbivory, because subsequent stem growth is initiated through the activation of lateral or adventitious buds below the point of stem removal (Archer and Tieszen 1980). However, by the mid-1920s wolves had been extirpated from Yellowstone NP (Schullery and Whittlesey 1992), and willows in Yellowstone's northern winter range, which comprises approximately $1500 \mathrm{~km}^{2}$ of mountainous terrain along the northeastern boundary of the park, began to experience many decades of heavy browsing, primarily by elk (Cervus elaphus; Kay 1990, Chadde and Kay 1996, Singer 1996, Meagher and Houston 1998, Barmore 2003).

In 1957 the National Park Service installed fenced exclosures at Tower Junction, Mammoth, and Lamar Valley in the northern elk winter range to assist in evaluating the potential effects of ungulate browsing. Measurements from 1958-1989, a period of over 3 decades, indicated that willows outside of the exclosures never exceeded $70 \mathrm{~cm}$ in height, while those on the inside had increased in height by over $600 \%$ (Singer 1996, Barmore 2003). These ex- closure studies led Kay (1990) and Barmore (2003) to conclude that ungulate browsing was the primary factor affecting suppressed aerial cover and height of willows. Similarly, willows in the Gallatin elk winter range along the northwestern corner of Yellowstone NP largely "died out" because of heavy browsing pressure from elk after wolves had been removed, while willows protected from browsing by an exclosure maintained a dense vigorous stand (Patten 1968, Ripple and Beschta 2004b).

During the winter of 1995, 14 gray wolves (Canis lupus), with an additional 17 wolves the following winter, were released into Yellowstone NP. By 2004, the northern range population consisted of approximately 85 wolves (Smith et al. 2005). Even though the northern range elk population comprised approximately 17,000 animals in 1996, it dropped to 11,700 elk following the severe winter of 1997 and further declined to about 8300 elk by 2004 . More detailed information on wolf and elk populations in the winter range can be found in Smith et al. (2003) and Ripple and Beschta (2004a).

Since wolf reintroduction, several ecosystem changes in the winter range have been noted. They include, for example, altered patterns of elk herbivory (Ripple et al. 2001, Fortin et al. 2005) and a spatially patchy increase in the heights of young willows and cottonwoods 


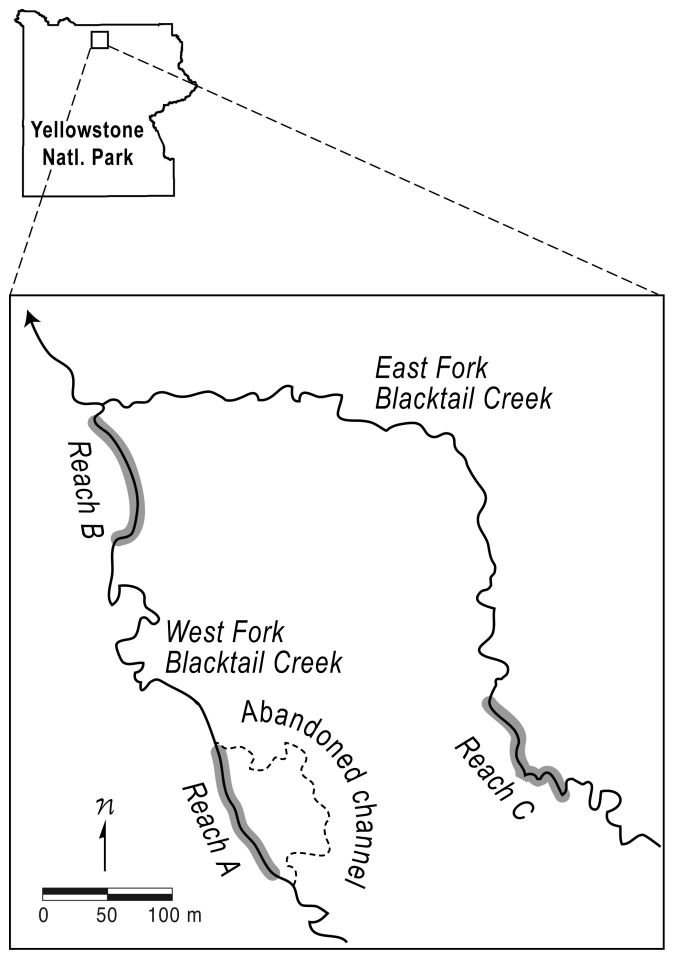

Fig. 1. Map of study reach locations on the Blacktail Deer Plateau in the northern elk winter range of Yellowstone National Park.

(Ripple and Beschta 2003, 2006). In addition, beaver (Castor canadensis) colonies are again reestablishing along some streams in the northern range (Smith et al. 2003).

We hypothesized that increased growth of woody browse species in riparian areas was occurring because of altered patterns of ungulate herbivory following the reintroduction of wolves into Yellowstone NP. To test this hypothesis, we evaluated recent patterns of willow herbivory and growth in the Blacktail Deer Plateau portion of the northern winter range. We also considered other environmental factors (e.g., height of plants above the water table or seasonal patterns of available moisture) as potential factors that might influence growth responses.

The Blacktail Deer Plateau consists of approximately $100 \mathrm{~km}^{2}$ of moderately sloping terrain (elevation 2000-2300 m). Sagebrush (Artemisia spp.)-grasslands and scattered aspen (Populus tremuloides) clones occur across much of the plateau and are interspersed with willowsedge (Carex spp.)-grass meadows in swales

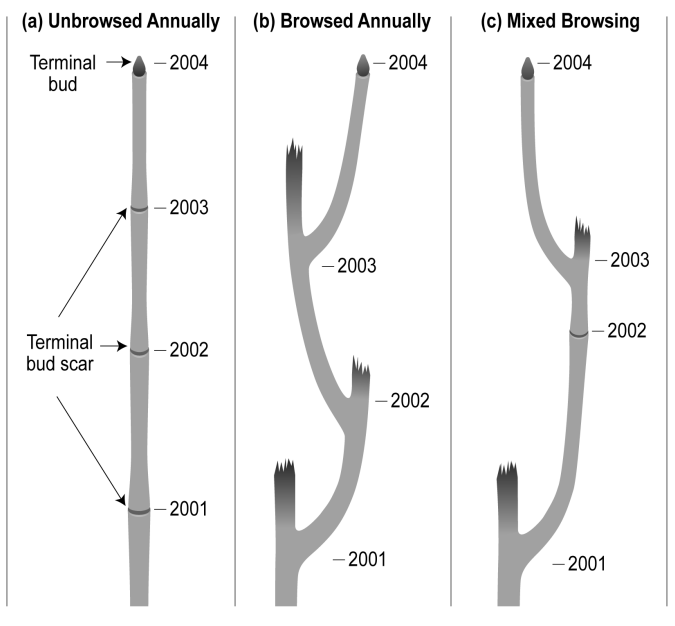

Fig. 2. Schematic of willow stems showing annual height growth without browsing (a), with browsing (b), and with an alternating pattern of browsing and nonbrowsing (c). Adapted from Keigley and Frisina (1998). Only stem segments for 2001-2004 are represented.

and on floodplains. The East and West Forks of Blacktail Deer Creek, with catchment areas of $21.6 \mathrm{~km}^{2}$ and $37.5 \mathrm{~km}^{2}$, respectively, drain a major portion of the plateau and have bankfull width-to-depth ratios of 8-10. Geyer willow (S. geyeriana) is the most prevalent willow species within the study area. Beaver are not present along Blacktail Deer Creek.

In late August 2004, we studied Geyer willow along three $100-\mathrm{m}$ reaches upstream of the East Fork-West Fork confluence of Blacktail Deer Creek at an elevation of $\sim 2025 \mathrm{~m}$ (Fig. 1). Two reaches on the West Fork (reaches A and B) and 1 on the East Fork (reach C) were selected to represent a range of willow community heights. For all reaches, a $4 \times 100$-m belt transect was located along the streambank. Within each $4 \times 4$-m segment of a transect ( 25 segments per transect) we chose the tallest live stem of Geyer willow for detailed measurements. For each selected stem, we used plant architecture techniques (Keigley and Frisina 1998, Ripple and Beschta 2004b) to evaluate its height and browsing history. If a stem had not been browsed, we simply measured the height above the ground of terminal bud scars for each year (Fig. 2a). Where browsing occurred, typically a part of the current annual growth (including the terminal bud) would have been removed, thus causing growth to emerge from a lateral bud. Browsed 

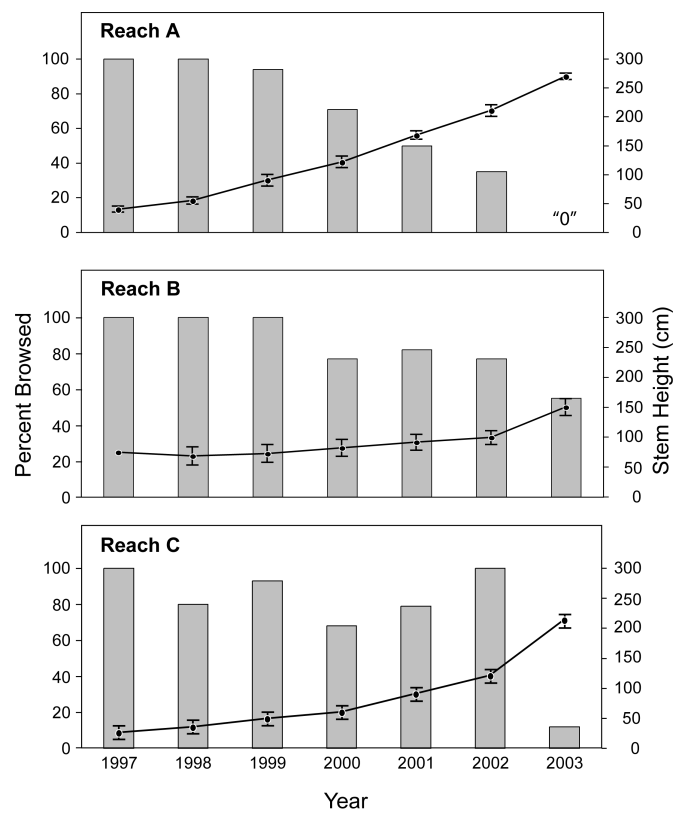

Fig. 3. Percent of stems browsed (shaded bars) and average plant height (lines) of Geyer willow for reaches A, B, and C. Standard errors for plant heights are also shown.

stems grew in a zigzag pattern and annual stem heights were determined at the point of branching (Fig. 2b). Thus, we were able to determine an average stem height, by year, along each transect as well as the percent of stems in each reach that had been browsed over the last 5-7 years. We also measured the height of each stem's root collar relative to the stream's water surface as well as the percent canopy cover that willows were providing over the stream. The nearest snow course (Lupine Creek) and stream gage (Lamar River) were used to characterize moisture patterns in recent years relative to long-term averages.

Willow measurements indicated that the proportion of stems browsed in 1997, 1 year after wolf reintroduction, was $100 \%$ for all reaches (Fig. 3). At reach A, browsing levels began to decrease in 1999 and attained $0 \%$ by 2003. In concert with reductions in herbivory, average stem heights of $39 \mathrm{~cm}$ along this reach in 1997 increased to $268 \mathrm{~cm}$ by 2003, a 7-fold increase. Average heights along reach $B$ ranged between 68 and $74 \mathrm{~cm}$ from 1997 to 1999, and even though browsing pressure dropped below 100\% during 2000-2003, only in 2003 did a major increase in plant height occur. By 2003, stem heights for reach B averaged $149 \mathrm{~cm}$. For reach C, average stem heights of $25 \mathrm{~cm}$ in 1997 increased to $212 \mathrm{~cm}$ by 2003 during a period of variable browsing levels. Thus, by 2003 all reaches had experienced decreased browsing and major increases in plant heights. While $83 \%$ of all stems $<200 \mathrm{~cm}$ in height were browsed, browsing was not observed on any stem that had attained a height of $>200 \mathrm{~cm}$. Linear regression between annual increase in willow height $(Y)$ and percent browsing $(X)$ for the 3 reaches indicated a significant inverse relationship $\left(Y=-0.65 X+73.6, n=18, r^{2}=\right.$ $0.64, P<0.01)$.

Willow heights in late August 2004, which included the unbrowsed current annual growth of that summer, averaged 290, 189, and $237 \mathrm{~cm}$ for reaches A, B, and C, respectively. The current annual growth in 2004 was $<50 \mathrm{~cm}$ for most stems and averaged 22,40 , and $24 \mathrm{~cm}$ for reaches $\mathrm{A}, \mathrm{B}$, and $\mathrm{C}$, respectively. Willow canopy coverage over the stream averaged $14 \%$, $25 \%$, and $73 \%$ for reaches $\mathrm{A}, \mathrm{B}$, and $\mathrm{C}$, respectively, a general improvement from the $<5 \%$ cover that was characteristic of these reaches in 1969 based on aerial photographs.

Root collar elevations of individual willow plants relative to the stream's water surface ranged from 0 to $90 \mathrm{~cm}$. However, linear regression indicated that willow heights in 2003 were not significantly $(P=0.16)$ related to the elevation of their root collars above the stream.

For 1997-2003, the annual maximum snowdepth (expressed as a percentage of the longterm average) for the Lupine Creek snow course averaged $11 \%$ below average. For these same years, springtime peak flows and August flows for the Lamar River gaging station averaged $24 \%$ above and $3 \%$ below their respective long-term averages.

Our willow measurements indicated that $100 \%$ of the sampled stems in each reach were browsed in 1997, which was early in the period of wolf recovery. Furthermore, average stem heights of between 25 and $74 \mathrm{~cm}$ for individual reaches in 1997 were essentially the same as those measured outside of exclosures in the northern range nearly 5 decades ago. However, with decreased browsing intensities in recent years, willow heights (Fig. 3) and general plant robustness (Fig. 4) have dramatically improved. Additionally, stems $>200 \mathrm{~cm}$ in height at this site appear to have grown above the normal 


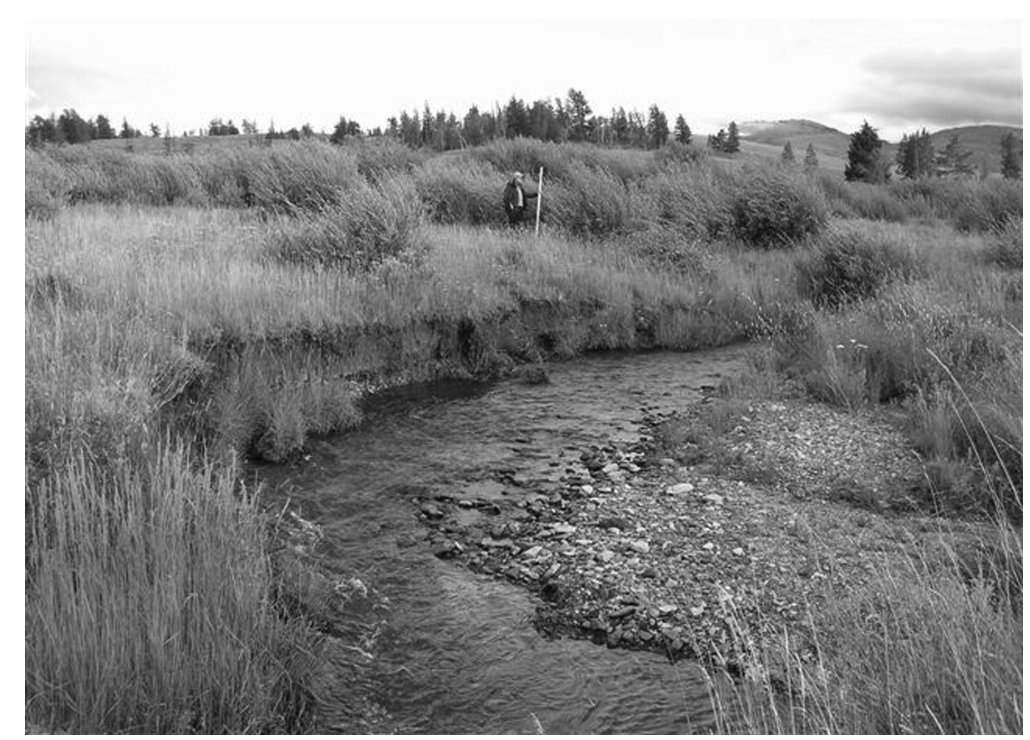

Fig. 4. A portion of reach A in August 2004 showing the general stature and growth form of recovering willows. Geyer willows along this reach averaged $<50 \mathrm{~cm}$ in height as recently as 1997, but by 2004 they had attained an average height of $290 \mathrm{~cm}$ (the vertical pole is $200 \mathrm{~cm}$ tall). The incised channel and the vertical eroding streambank occurred prior to the recent increase in willow heights.

browse level of elk. It is important to note that willow height increases during the period 19972003 (when wolves were present) occurred when northern range elk densities were several times higher than in the mid-1960s, when height increases were not observed and when wolves were absent.

Our results indicate that height of root collar above the adjacent stream's water surface (as an index of available moisture) was not a significant factor affecting willow growth. In Rocky Mountain National Park, Zeigenfuss et al. (2002) evaluated willow (S. monticola, S. planifolia, and S. geyeriana) production relative to elk herbivory and varying water table depths. While elk browsing lowered willow production, water table depths, ranging from 0 to $100 \mathrm{~cm}$, had little effect on the productivity of willows and other shrubs.

Winter snowpack depths are often a primary factor affecting snowmelt runoff (i.e., magnitude of high flows and their duration) in the following spring. In turn, the magnitude of annual peak flows can affect soil moisture recharge along floodplains and create favorable conditions for the establishment and initiation of seasonal plant growth. Summer base flows help to maintain local water tables that are often a cru- cial source of moisture for many riparian plants during the growing season. Even though snowpack depths, peak flows, and July flows varied during 1997-2003, a period when willow heights began to increase, similar variability in these hydrologic indicators has been common during the previous decades when height increases of Geyer willow were not observed. Such results indicate that the availability of seasonal moisture has not had a major influence on (1) the lack of willow growth during the decades when wolves were absent or (2) willow height increases in recent years when wolves were present.

Overall, the increased height growth of willows reported herein is consistent with other reports of increased growth by young cottonwoods (Ripple and Beschta 2003) and willows (Ripple and Beschta 2005, 2006, Beyer 2006) in other portions of the winter range as well as growth of willows in the Gallatin elk winter range where wolves have also returned (Ripple and Beschta 2004b). The increased stature of these woody browse species may ultimately lead to enhanced riparian functions (e.g., more stable streambanks, increased shading and thermal moderation of aquatic habitats, and improved food web support for aquatic and 
terrestrial biota) relative to previous decades when woody species in riparian areas had been suppressed by browsing.

Our findings support the hypothesis that reductions in elk browsing of riparian willow communities following the 1995-1996 wolf reintroduction are the result of a trophic cascade involving wolves, elk, and deciduous woody vegetation. Any such cascade would likely include some combination of changes in elk browsing patterns and habitat use due to predation risk, as well as reduced elk densities due to the mortality effects of predation (Ripple and Beschta 2004a, Beyer 2006). More recently, Creel et al. (2007) found elk fecundity effects associated with predation risk.

Because of their ability to withstand significant browsing pressure while continuing to increase in height and canopy cover, willows may represent a "leading edge" indicator regarding the recovery of other deciduous woody species (e.g., aspen, cottonwood, berry-producing shrubs) and herbaceous species. If willows and other woody browse species continue to reoccupy former habitats and increase in height, a recovery of the structure and functions associated with these plant communities may again provide a wide range of ecological benefits in Yellowstone's northern winter range.

\section{Literature Cited}

Archer, S., And L.L. Tieszen. 1980. Growth and physiological responses of tundra plants to defoliation. Arctic Alpine Research 12:531-552.

BARMORE, W.J. 2003. Ecology of ungulates and their winter range in northern Yellowstone National Park: research and synthesis 1962-1970. Yellowstone Center for Resources, Yellowstone National Park, WY.

Beyer, H. 2006. Wolves, elk and willow on Yellowstone National Park's northern range. Master's thesis, University of Alberta, Edmonton, Alberta, Canada.

Chadde, S., AND C.E. Kay. 1996. Tall-willow communities on Yellowstone's northern range: a test of the "natural regulation" paradigm. Pages 165-184 in F.J. Singer, editor, Effects of grazing by wild ungulates in Yellowstone National Park. USDI National Park Service, Technical Report NPS/NRYELL/NRTR/96-01, Denver, CO.

Creel, S., D. Christianson, S. Liley, and J.A. Winnie, JR. 2007. Predation risk affects reproductive physiology and demography of elk. Science 315:960.

Fortin, D., H.L. Beyer, M.S. Boyce, D.W. Smith, T. Duchesne, AND J.S. MaO. 2005. Wolves influence elk movements: behavior shapes a trophic cascade in Yellowstone National Park. Ecology 86:1230-1330.

KAY, C.E. 1990. Yellowstone's northern elk herd: a critical evaluation of the "natural regulation" paradigm. Doctoral dissertation, Utah State University, Logan.
Keigley, R.B., AND M.R. Frisina. 1998. Browse evaluation by analysis of growth form. Montana Department of Fish, Wildlife, and Parks, Helena.

Meagher, M., and D.B. Houston. 1998. Yellowstone and the biology of time: photographs across a century. University of Oklahoma Press, Norman.

National Park Service. 1997. Yellowstone's northern range: complexity and change in a wildland ecosystem. USDI National Park Service, Yellowstone National Park, Mammoth Hot Springs, WY.

PATtEN, D.T. 1968. Dynamics of the shrub continuum along the Gallatin River in Yellowstone National Park. Ecology 49:1107-1112.

RipPle, W.J., AND R.L. BESChTA. 2003. Wolf reintroduction, predation risk, and cottonwood recovery in Yellowstone National Park. Forest Ecology and Management 184:299-313.

2004a. Wolves and the ecology of fear: can predation risk structure ecosystems? BioScience 54:55766.

2004b. Wolves, elk, willows, and trophic cascades in the upper Gallatin Range of southwestern Montana, USA. Forest Ecology and Management 200: $161-181$.

2005. Willow thickets protect young aspen from elk browsing after wolf reintroduction. Western North American Naturalist 65:118-122.

2006. Linking wolves to willows via risk-sensitive foraging by ungulates in the Northern Yellowstone Ecosystem. Forest Ecology and Management 230:96106.

Ripple, W.J., E.J. LaRsen, R.A. Renkin, and D.W. Smith. 2001. Trophic cascades among wolves, elk and aspen on Yellowstone National Park's northern range. Biological Conservation 102:227-234.

Schullery, P., AND L. WhitTlesey. 1992. The documentary record of wolves and related wildlife species in Yellowstone National Park area prior to 1882. Pages 1-174 in J.D. Varley and W.G. Brewster, editors, Wolves for Yellowstone? A report to the United States Congress. Volume IV, research and analysis. USDI National Park Service, Yellowstone National Park, Mammoth Hot Springs, WY.

Singer, FJ. 1996. Differences between willow communities browsed by elk and communities protected for 32 years in Yellowstone National Park. Pages 279290 in F.J. Singer, editor, Effects of grazing by wild ungulates in Yellowstone National Park. USDI National Park Service, Natural Resource Information Division, Technical Report NPS/NRYELL/NRTR/ 96-01, Denver, CO.

Smith, D.W., R.O. Peterson, and D.B. Houston. 2003. Yellowstone after wolves. BioScience 53:330-340.

Smith, D.W., D.R. Stahler, and D.S. Guernsey. 2005. Yellowstone wolf project; annual report. USDI National Park Service, Yellowstone Center for Resources, YCR-2006-04, Yellowstone National Park, WY.

Zeigenfuss, L.C., F.J. Singer, W.A. Williams, T.L. JohnSON. 2002. Influences of herbivory and water on willow in elk winter range. Journal of Wildlife Management 66:788-795.

Received 9 May 2006 Accepted 13 July 2007 